NINA W. HARLAND

\title{
R v Mika \\ An investigation into the Court of Appeal's neglect of s 27 of the Sentencing Act 2002
}

\author{
Submitted for the LLB (Honours) Degree
}

Faculty of Law

Victoria University of Wellington 


\begin{abstract}
The Court of Appeal in the case of $R v$ Mika failed to engage with section 27 of the Sentencing Act 2002 in dismissing Mr Mika's appeal against his sentence. In both the High Court and Court of Appeal the focus was on Mr Mika's argument for a discount of 10 per cent to be applied to his sentence to reflect his Māori heritage and associated social disadvantages. Section 27 of the Sentencing Act would allow a court to take into account cultural information regarding Maori offenders' backgrounds and the systemic disadvantages stemming from this. In dismissing Mika's appeal, the Court erred in not considering the clear signals from Parliament that the judiciary were to take into account Maori offenders' backgrounds at the sentencing stage through s 27 in an effort to fit appropriate sentences to Maori offenders. Recent developments in Canada have seen the Canadian judiciary recognise their role in the over-representation of Aboriginal people in the Canadian prison population. The New Zealand judiciary can take lessons from the willingness of the Canadian judiciary to take cultural information into account at sentencing.
\end{abstract}

Key words: $R v$ Mika, Sentencing Act, cultural background, section 27, Māori 


\section{Table of Contents}

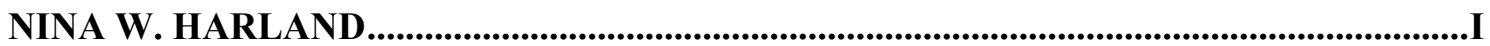

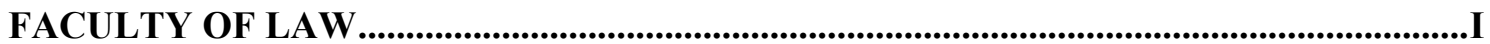

VICTORIA UNIVERSITY OF WELLINGTON

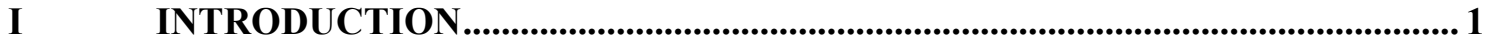

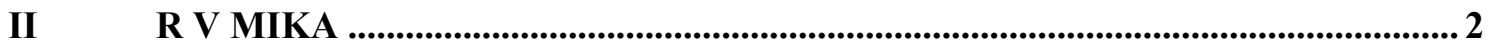

A The Dismissal by the Court of Appeal....................................................................... 2

III THE COURT ERRED IN NOT ADEQUATELY TAKING INTO ACCOUNT

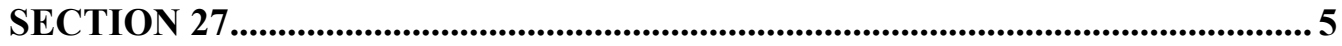

A Over-representation of Māori in the New Zealand Criminal Justice System ........ 5

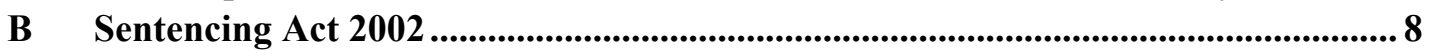

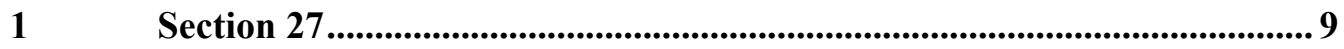

$2 \quad$ Section 27 enacted with Māori in mind ................................................. 11

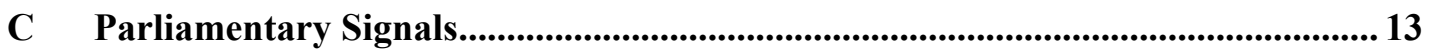

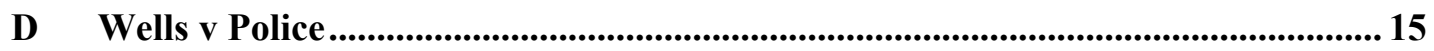

IV SECTION 27(5) DISCRETION AVAILABLE TO THE JUDICIARY ............... 17

A The Court's Failure to Exercise this Discretion ............................................................ 17

B Factors to Consider in Exercise of Discretion ......................................................... 18

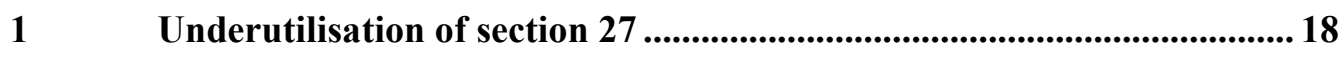

2 The judiciary's acknowledgment of the importance of a section 27

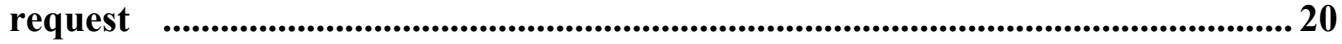

$\mathrm{V}$ OTHER FACTORS INDICATING THE COURT WAS MISGUIDED ............... 21

A Focus on the Sentencing Discount ............................................................................... 21

B Insufficient Work Done on how to Reflect Section 27 in Sentencing Options...... 22

C Failure to Take into Account Overseas Jurisdictions .......................................... 22

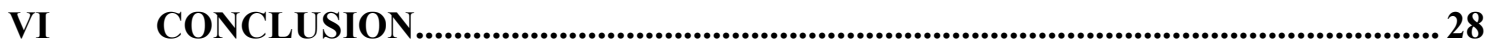

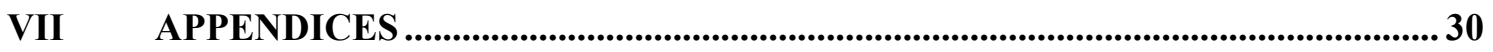

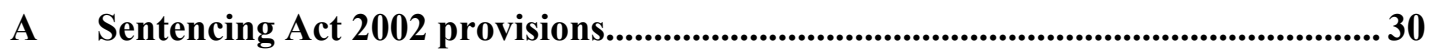

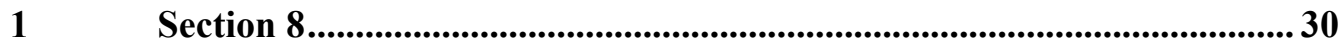

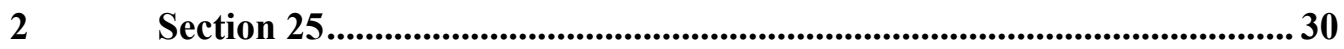

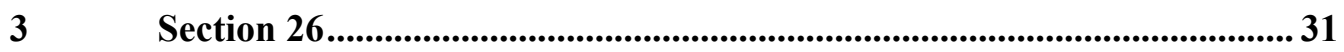

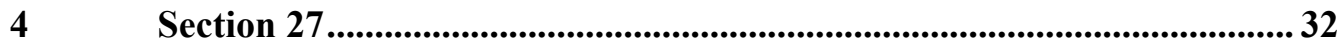

B Criminal Justice Act 1985 provisions ........................................................................... 33

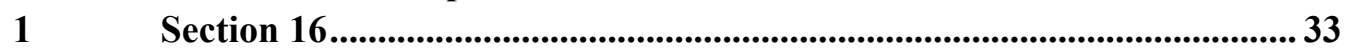

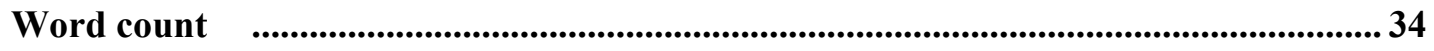

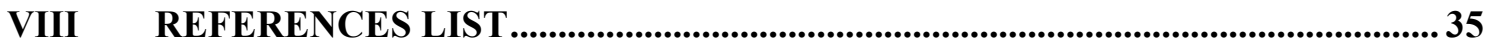

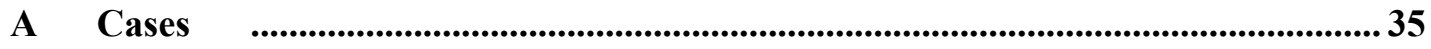

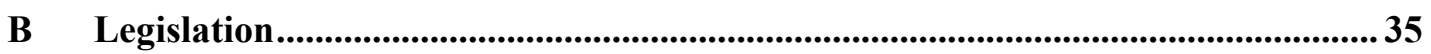

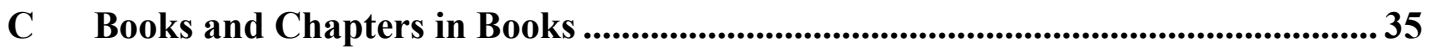

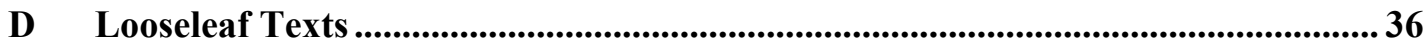

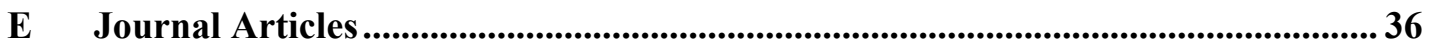

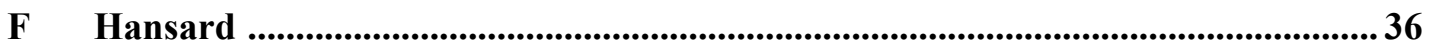

G Government Papers and Reports ..................................................................................... 36

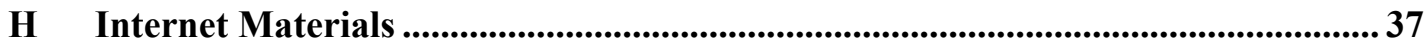




\section{Introduction}

The Court of Appeal in Mika $v R^{l}$ erred in its decision to dismiss Fabian Mika's appeal against his sentence by failing to acknowledge the appropriate statutory provisions and the New Zealand Parliament's clear signals that the judiciary was expected to deal with Māori over-representation in the New Zealand prison population.

Parliament acknowledged Māori over-representation within the New Zealand justice system, with the introduction of the Criminal Justice Act 1985, s 16, the precursor to the Sentencing Act 2002, s 27. The provision was originally enacted as a response to the overrepresentation of Māori in the NZ prison population. Section 27 allows judges to gain insight into the cultural backgrounds of all offenders generally, and can be used to focus on Māori offenders specifically. Section 27(5) allows the judiciary to suggest to the offender that it may be of assistance to the court to hear a person speak on the matters in $\mathrm{s}$ 27(1). This paper focuses on the exercise of this discretion. Currently, as typified by $R v$ Mika, the provision does not serve its intended purpose.

The High Court ${ }^{2}$ and Court of Appeal, dismissed Mika's argument for a 10 per cent sentencing discount to reflect his Māori heritage and associated disadvantages. The Judges acknowledged s 27, but failed to apply it. The onus is on the offender to request a person speak, but the judge has discretion to suggest to the offender it may be of assistance to hear a person speak. ${ }^{3}$ The Court failed to consider all relevant matters in declining to use its discretion under s 27(5). Counsel for Mika, Mr Rapley, failed to argue the provision. Parliament had an expectation when enacting s 27 that the Court would address overrepresentation, and inquire after all the appropriate information before deciding a sentence. By refusing to exercise the discretion the court did not ensure all relevant information was before it, in order to make the best decision. Further, these Parliamentary signals were

\footnotetext{
${ }^{1}$ Mika v R [2013] NZCA 648.

${ }^{2} R v$ Mika [2013] NZHC 2357.

${ }^{3}$ Sentencing Act 2002, s 27(5).
} 
interpreted in Wells $v$ Police ${ }^{4}$, which the Court neglected to consider. The Court of Appeal was careful to avoid using ethnicity as a mitigating factor in deciding Mika's sentence, nevertheless it was the Court's duty to use its discretion to inquire after information under s 27(5). A sentence discount was considered inappropriate to address over-representation, yet the Court failed to apply fully the one measure specifically enacted for that purpose.

The Court of Appeal was too quick to declare consideration of Mika's cultural background unworkable within the current legislative framework. This is out of step with the Canadian Supreme Court, in recent years, recognising the issue of over-representation of its Aboriginal $^{5}$ people in the Canadian prison population. The similar Canadian provision was accepted as a mandatory sentencing step for Aboriginal offenders, whereas in New Zealand s 27 provides a judicial discretion. Mika highlights the judiciary's failure to exercise their s 27(5) discretion to prevent injustices. A balance must be struck between seeking information and the efficacious delivery of justice, therefore s 27 should be applied where Māori offenders are facing serious charges, or the court is deciding between sentences; for example a custodial sentence of certain length versus another length or a custodial and noncustodial sentence. This would give effect to Parliament's intent for the provision to provide further information for judges sentencing Māori offenders as a method of remedying over-representation. Parliament's signals should be acted upon; s 27 should apply regardless of the fact that the offender fails to encourage sympathy for their situation as evidenced by Mika.

II $R$ v Mika

\section{A The Dismissal by the Court of Appeal}

\footnotetext{
${ }^{4}$ Wells v Police [1987] 2 NZLR 560 (HC).

${ }^{5}$ When referring to Aboriginal peoples of Canada, the designation comprises of the First Nations, Inuit and Métis peoples.
} 
On 12 December 2013 the New Zealand Court of Appeal, comprising of Harrison, Simon France and Dobson JJ, dismissed Fabian Mika's appeal against his sentence of six years and nine months imprisonment. Mika pleaded guilty in the High Court to charges of manslaughter ${ }^{6}$, failing to comply with a prohibition as an unlicensed driver $^{7}$, failing to stop or ascertain injury or death after a $\operatorname{crash}^{8}$ and failing to stop when followed by red and blue flashing lights. ${ }^{9}$ Mika appealed against his sentence on the ground that it was manifestly excessive because the Judge failed to adopt a 10 per cent sentencing discount to reflect his Māori heritage and the associated social disadvantages. ${ }^{10}$ The judgment focused on the discount, perhaps due to the application of discounts of up to 25 per cent for guilty pleas. ${ }^{11}$ Section 27 was raised in both the High Court and the Court of Appeal judgments, yet the failure to apply the section indicates the judiciary did not consider the precedent and Parliament's intent. The Court of Appeal referred to s 27 briefly:

[14] Finally, we note, as did David Gendall $\mathrm{J}$ in the High Court, that s 27 of the Sentencing Act entitles an offender to request the Court before sentencing to hear any person or persons called to speak on, among other things, the offender's whānau and cultural background. It was open to Mr Rapley to take this step, but he did not do so.

Mika's appeal for a 10 per cent discount was based on a number of interrelated claims regarding Māori heritage and its bearing on sentencing in New Zealand. ${ }^{12}$ Counsel for Mika submitted that a failure occurred in not taking into account the systemic and background factors that may contribute to offending by Māori; ${ }^{13}$ the Māori background of an offender may point to the need for alternative sanctions $;{ }^{14}$ generally the court did not factor into the sentencing process the tendency of Māori offenders receiving longer jail terms than their

\footnotetext{
${ }^{6}$ Crimes Act 1961, ss 160(2)(a), 171 and 177.

${ }^{7}$ Land Transport Act 1998, s 52(1)(c).

${ }^{8}$ Land Transport Act 1998, s 36(1)(c).

${ }^{9}$ Land Transport Act 1998, s 52(1)(c).

${ }^{10}$ Mika $v$ R, above n 1, at [2].

${ }^{11} R v$ Mika, above $\mathrm{n} 2$, at [54].

${ }^{12}$ At [6].

${ }^{13}$ At [6].

${ }^{14}$ At [6].
} 
non-Māori counterparts. ${ }^{15}$ These considerations were supported by Canadian and Australian judgments where offenders' indigenous backgrounds were considered in sentencing, in an effort to reduce numbers in prison. ${ }^{16}$ It was open to the Court of Appeal to address these issues at sentencing within New Zealand's legislative context.

Mika's appeal was dismissed for a number of reasons. The Court of Appeal sat as a Divisional Court ${ }^{17}$ and declared it was not the place to decide on sentencing principles and policy without the proper evidential foundation. ${ }^{18}$ The Court of Appeal declined to read into the Sentencing Act any special sentencing conditions for Māori offenders. The Act was declared a "comprehensive code" whereby the sentencing provisions Parliament requires courts to follow are prescribed without reference to 'ethnicity' ${ }^{19}$ Specifically s 8 , outlining the principles of sentencing, and s 9, the aggravating and mitigating factors, omit the word 'ethnicity', though it was acknowledged s 9 is not an exhaustive list. ${ }^{20}$ The Court resolved, if ethnicity mandated an "absolute requirement" that a court apply a fixed discount, this could only be sanctioned by Parliament and would have been made plain in the Sentencing Act or in another statute. ${ }^{21}$ Therefore, it was unlikely Parliament intended the Sentencing Act apply a blanket discount to all Māori offenders' sentences, regardless of offender, offence and culpability factors. The Court of Appeal was reluctant to draw on the Canadian and Australian authorities in making this decision regarding indigenous sentencing. Without identifying the differences in the statutory contexts, the Court concluded the authorities were of "no assistance". ${ }^{22}$ Mika's case did not invoke great sympathy from the judiciary or the general public. ${ }^{23}$ It was dismissed for the

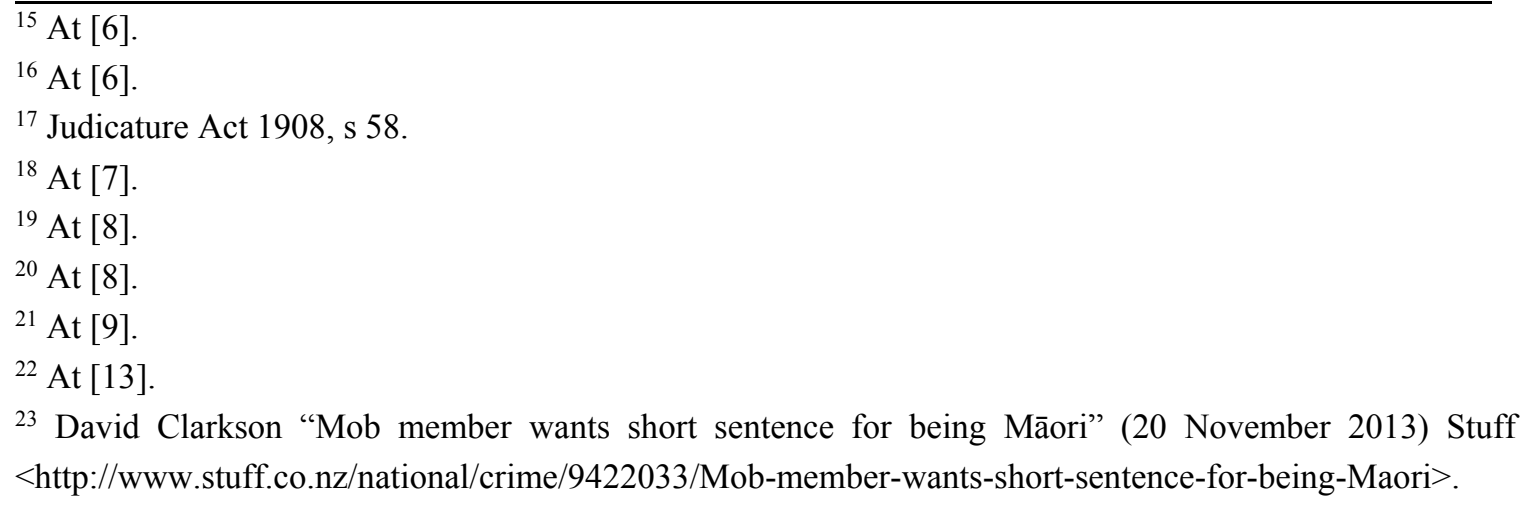


aforementioned reasons without looking to the New Zealand jurisprudence and discretion afforded to the judiciary under s 27(5).

A significant aspect of the decision was the Court of Appeal's acknowledgment of the overrepresentation of Māori in the New Zealand prison population. The leading judgment of the appellate court declared judges "are acutely conscious of that factor and its reflection of the economic, social and cultural disadvantages suffered by many Māori. We accept that those circumstances frequently contribute to offending." ${ }^{24}$ However, the Court dismissed the argument that these disadvantages entitled Māori to a blanket discount as "it does not logically follow that a person is more likely to be at a disadvantage and to offend simply by virtue of his or her Māori heritage." 25 The Court went as far as to state the proposition was conceivably offensive, although presumably not to Māori offenders at the sentencing stage. The Court recognised the disproportionate imprisonment of Māori and s 27 brought the issue within their purview, yet the Court remained silent on the issue. The acknowledgement of Māori over-representation was the only statement of great value in the judgment.

\section{The Court Erred in not Adequately Taking into Account Section 27}

\section{A Over-representation of Māori in the New Zealand Criminal Justice System}

Within the New Zealand criminal justice system generally and the prison population specifically, Māori are over-represented in comparison to the general population. According to the Ministry of Justice as at 31 March 2013, Māori represented 50 per cent of the prison population, while making up only 14 per cent of the general population. ${ }^{26}$

\footnotetext{
${ }^{24}$ At [12].

${ }^{25}$ At [12].

${ }^{26}$ Ministry of Justice United Nations convention against torture: New Zealand draft periodic report 6 (2013) at [158].
} 
Khylee Quince noted that, the over-representation exists throughout the criminal justice system: ${ }^{27}$

As well as disparities at the front end in the over-policing, charging and conviction of Māori, there are differences in the outcomes imposed on Māori in the criminal justice system. Seven times as many Māori as non-Māori are given a custodial sentence upon conviction. Māori are far less likely to be granted leave for home detention, or to receive a fiscal penalty.

Quince's observations are borne out by recent New Zealand Ministry of Justice statistics indicating that of the adults convicted in 2012/13, 41 per cent were European, 38 per cent were Māori and 10 per cent Pacific peoples. ${ }^{28}$ These statistics indicate a problem exists, with Māori significantly over-represented.

In 2011, Kim Workman addressed the issue of Māori over-representation within the criminal justice system and examined whether the issue was attributable to structural discrimination. ${ }^{29}$ Evidence, including Māori being four to five times more likely to be apprehended, prosecuted and convicted than non-Māori, led Workman to comment: ${ }^{30}$

... we know what is happening, there seems to be a collective reluctance on the part of the government and its agencies to delve further into this information, and try to understand why this is happening.

\footnotetext{
${ }^{27}$ Khylee Quince "Māori and the Criminal Justice System in New Zealand" in Warren Brookbanks and Julia Tolmie (eds) Criminal Justice in New Zealand (LexisNexis NZ, Wellington, 2007) 333 at 334.

${ }^{28}$ Ministry of Justice Trends in Conviction and Sentencing - Court statistics for adults (aged 17 and over) for year ended June 2013 (2013) at 2.

${ }^{29}$ Kim Workman "Māori Over-representation in the Criminal Justice System - Does Structural Discrimination Have Anything to Do with It?" (8 November 2011) Rethinking Crime and Punishment $<$ http://www.rethinking.org.nz/assets/Newsletter_PDF/Issue_105/01_Structural_Discrimination_in_the_CJ S.pdf $>$ at 2 .

${ }^{30}$ Workman, above n 29, at 14.
} 
The current over-representation trend cannot continue, a fundamental shift in attitude is necessary. ${ }^{31}$

The 2007 Department of Corrections report 'Over-representation of Māori in the Criminal Justice System' identifies that New Zealand's criminal justice system “deliberately seeks to be 'blind' to much of the accused person's personal and social circumstances." 32 This is true of New Zealand's criminal law which focuses on individual liability. The report finds there may be strength in a less individualised response to offending due to the multifaceted nature of the issues involved. ${ }^{33}$ Allowing more cultural based information to be placed before the courts transforms the concept of individualised justice and introduces the notion of collective justice to the criminal justice system. Account should perhaps be taken of matters that affect the collective Māori community. The factors affecting a Māori offender may extend beyond the individual and their ethnicity, rather encompassing their cultural background and history, including social and economic disadvantages. ${ }^{34}$ Indeed, the report's authors concluded: "Māori over-representation is not a 'Māori' problem at all.,"35

Many minority ethnic groups present in New Zealand may be over-represented in criminal justice statistics. ${ }^{36}$ Therefore, a practical approach targeting Māori offenders may be viewed as preferentialism. However, the sheer numbers of Māori in New Zealand prisons creates urgency. With Māori comprising 14 per cent of New Zealand society, yet representing half of the prison population, the number of incarcerated Māori leaves a void

\footnotetext{
${ }^{31}$ Workman, above n 29, at 24.

${ }^{32}$ Department of Corrections Over-representation of Māori in the criminal justice system: An exploratory report (September 2007) at 38.

${ }^{33}$ At 38 .

${ }^{34}$ Department of Corrections Over-representation of Māori in the criminal justice system: An exploratory report, above $\mathrm{n} 32$, at 38 .

${ }^{35}$ At 38 .

${ }^{36}$ Bronwyn Morrison Identifying and Responding to Bias in the Criminal Justice System: A Review of International and New Zealand Research (Ministry of Justice, November 2009) at 18.
} 
in the offenders' families and communities. ${ }^{37}$ Valmaine Toki declared the issue of indigenous people over-represented in prison populations to be endemic. ${ }^{38}$

The Court of Appeal accepted in Mika the over-representation of Māori was an issue in New Zealand, but declined to make a decision on how to approach this. ${ }^{39}$ Both the High Court and the Court of Appeal focused on the appropriateness of setting a discount, but ignored that Mika had not requested cultural information be brought before the court under s 27. The Court had the opportunity to call for cultural information under s 27(5) and failed to do so. Max Harris was disappointed by the Court's failure to take action to address overrepresentation: ${ }^{40}$

The problem is regarded by many as a national disgrace, which requires urgent action by politicians - and recognition of this fact by the Court might have fortified its conclusions based on the wording of the Sentencing Act.

\section{B Sentencing Act 2002}

The Sentencing Act provides judges with mechanisms through which the cultural background of offenders and the systemic disadvantages affecting Māori may be considered. The over-representation of Māori was an important consideration in the drafting of the Sentencing Act. ${ }^{41}$ Sections 8, 26 and 27 provide for cultural information to be considered at sentencing. Principle 8(i) provides a foundation for taking into account cultural information: ${ }^{42}$

\footnotetext{
${ }^{37}$ Department of Corrections Over-representation of Māori in the criminal justice system: An exploratory report, above $\mathrm{n} 32$, at 39 .

${ }^{38}$ Valmaine Toki "Domestic Violence and Women: Can a Therapeutic Jurisprudence Approach Assist?" (2009) 78 Rev. Jur. U.P.R. 61 at 62.

${ }^{39}$ At [12].

${ }^{40}$ Max Harris "Criminal law, sentencing and ethnicity - sensible [or] superficial?" (2014) February Māori LR 20 at 24.

41 (12 June 1985) 463 NZPD 4759.

${ }^{42}$ For the full section 8 see appendix A.1.
} 
8 In sentencing or otherwise dealing with an offender the court-

(i) must take into account the offender's personal, family, whānau, community, and cultural background in imposing a sentence or other means of dealing with the offender with a partly or wholly rehabilitative purpose

It is mandatory for the court to consider this principle in sentencing an offender. Section 8 principles provide a sentencing base and allow for the use of other mechanisms by which cultural factors may play a role. Section 25 allows the court to adjourn proceedings to allow for inquiries into a suitable punishment for the offender. ${ }^{43}$

Section 26 pre-sentence reports, include information regarding the personal, family, whānau, community, and cultural background, and social circumstances of the offender. ${ }^{44}$ These provisions provide the mechanisms by which cultural information can be placed before the court. Max Harris stated, "The Court might have concluded upon analysing these provisions that an ethnicity-based discount was entirely coherent and consistent with the purpose and spirit of the Sentencing Act." 45 The Court of Appeal did not take sufficient account of the foundation provisions that allow for cultural information to be called on by a court under s $27(5)$.

\section{$1 \quad$ Section 27}

Section 27 of the Sentencing Act may prove itself vital for addressing the overrepresentation of Māori in New Zealand prisons. The section provides: ${ }^{46}$

27 Offender may request court to hear person on personal, family, whānau, community, and cultural background of offender

\footnotetext{
${ }^{43}$ For the full section 25 see appendix A.2.

${ }^{44}$ Sentencing Act 2002, s 26(2)(a). For the full section 26 see appendix A.3.

${ }^{45}$ Harris, above n 40, 24.

${ }^{46}$ For section 27 see appendix A.4.
} 
(1) If an offender appears before a court for sentencing, the offender may request the court to hear any person or persons called by the offender to speak on-

(a) the personal, family, whānau, community, and cultural background of the offender:

(b) the way in which that background may have related to the commission of the offence:

(c) any processes that have been tried to resolve, or that are available to resolve, issues relating to the offence, involving the offender and his or her family, whānau, or community and the victim or victims of the offence:

(d) how support from the family, whānau, or community may be available to help prevent further offending by the offender:

(e) how the offender's background, or family, whānau, or community support may be relevant in respect of possible sentences.

(2) The court must hear a person or persons called by the offender under this section on any of the matters specified in subsection (1) unless the court is satisfied that there is some special reason that makes this unnecessary or inappropriate.

(3) If the court declines to hear a person called by the offender under this section, the court must give reasons for doing so.

(4) Without limiting any other powers of a court to adjourn, the court may adjourn the proceedings to enable arrangements to be made to hear a person or persons under this section.

(5) If an offender does not make a request under this section, the court may suggest to the offender that it may be of assistance to the court to hear a person or persons called by the offender on any of the matters specified in subsection (1).

Section 27 is a presumptive entitlement, allowing an offender to request the court hear a person speak on their personal, family, whānau, community and cultural background. Importantly, these cultural factors may relate to the commission of the offence or possible sentences. Section 27(5) is an important provision allowing the court to inquire after information on the offender where they consider it useful. There is no requirement for the person called on to speak on the matters in s 27(1) to give evidence under oath, they may speak outside the witness box and without cross-examination; this encourages informal 
communication of evidence. ${ }^{47}$ The explicit recognition that an offender's cultural background may contribute to offending on an individual basis, is quite exceptional. ${ }^{48}$ Effectively, s 27 provides a foundation for the judiciary, to take into account matters specific to Māori offenders, such as offenders' backgrounds and historic disadvantage, at sentencing.

\section{Section 27 enacted with Māori in mind}

Section 27 does not single out Māori as the intended recipients of the presumptive entitlement. Nevertheless, the section may have been implemented to address the overrepresentation of Māori offenders specifically, notwithstanding that the section is worded broadly to encompass all ethnic groups. As will be discussed further below, the passage of s 27's predecessor, s 16 of the Criminal Justice Act 1985, is instructive. The Minister of Justice at the time of the Criminal Justice Bill's second reading, the Rt Hon Sir Geoffrey Palmer, revealed the purpose of s 16 was to "secure the co-operation of ethnic minorities that at present experience high rates of imprisonment in seeking ways of finding alternatives to imprisonment." 49 The provision was framed generally to avoid the inevitable arguments of preferentialism of Māori over other racial groups. ${ }^{50}$ Māori being the most over-represented group in criminal justice statistics would have been influential in drafting the Bill. To remedy the over-representation of Māori, the New Zealand judiciary would need to make a conscious effort to sentence Māori with regard to the available provisions of the Sentencing Act, looking to the systemic disadvantages and societal issues plaguing the offender.

\footnotetext{
${ }^{47}$ Bruce Robertson (ed) Adams on Criminal Law - Sentencing (online looseleaf ed, Brookers) at [SA27.01].

48 Sam Jeffs "Māori Overrepresentation and the Sentencing Act: The Role of Cultural Background" (19 September 2013) New Zealand Human Rights Blog <http://nzhumanrightsblog.com/policy/maorioverrepresentation-and-the-sentencing-act-the-role-of-cultural-background/\#more-517>.

49 (23 July 1985) 464 NZPD 5834.

50 (23 July 1985) 464 NZPD 5834.
} 
The wording of s 27 strongly indicates the provision should be read as applying especially to Māori offenders. At numerous points throughout the Sentencing Act, 'whānau' is a factor often in consideration when determining a sentence. A dictionary of Māori legal terms defines whānau as: ${ }^{51}$

Kin linked by a living or recent ancestor. The meaning now extends to family, a multigeneration group consisting of parents, children (including adopted children) and their spouses, and grandchildren. In modern usage it includes various special interest groups whose members function as a kin.

Section 27 sets out 'whānau' as one of the matters a person may speak on under s 27(1). The provision makes no mention of another cultural kin based collective entity. The individual nature of New Zealand's criminal law liability means that the greater the offending and the higher the harm caused by the offending, the less the court can take into account the individual circumstances of the offender. However, the term 'whānau' could be interpreted in such a way as to require collective justice to be taken into account at sentencing.

The judiciary are empowered to acknowledge Māori as a group to whom the application of s 27 is necessary. The specific mention of 'whānau' may entitle the Court to read in the importance of s 27 when sentencing Māori offenders. In cases where the offenders do not call on the provision, the court should step in under s 27(5), unless specifically waived by the offender. The Court of Appeal in Mika were concerned that a blanket discount of 10 per cent would constitute judicial overreach. This paper does not advocate a discount for Māori offenders. However, the judiciary are able to encourage the use of s 27 for Māori offenders appearing for sentencing, this would not amount to judicial overreach as space exists in the legislation for this interpretation. Further, this is in line with Parliament's original intention for the provision. The specific mention of whānau and the purpose of the

\footnotetext{
${ }^{51}$ Māmari Stephens and Mary Boyce (eds) He Papakupu Reo Ture: A Dictionary of Māori Legal Terms (LexisNexis, Wellington, 2013) at 121.
} 
legislation to deal with Māori over-representation point to the conclusion that cultural considerations at sentencing are necessary for Māori offenders especially.

The Ministry of Justice introduced s 16 with the aim of reducing imprisonment by engaging with communities, encouraging community based sentences. ${ }^{52}$ The legislators clearly envisaged a sentencing practice where the whanau and wider community were encouraged to participate in an attempt to understand the options available when sentencing a Māori offender. Involving different cultures would enable communities to find alternatives to imprisonment for members of their communities who offend.

The text of both provisions leads me to conclude s 27 is an expansion of s 16; the introduction of the word 'whānau', the excision of 'ethnic background' and the introduction of the relevancy of cultural background to possible sentences.

\section{Parliamentary Signals}

The current provision has been greatly expanded from its predecessor, $\mathrm{s} 16$ of the Criminal Justice Act 1985. ${ }^{53}$ Section 27 reflects its predecessor, in addition it allows a person to be called upon to speak on a broader range of matters. Paragraphs (c) and (e) were entirely new in the Sentencing Act, expanding the provision's scope to enable the court to take into account processes that may have been taken, or could be taken, to resolve the issues relating to the offence as well as the relevance of the offenders' background factors in relation to possible sentences. Section 27's expansion may reflect a desire for more situations under which the offender's cultural background may play a part in sentencing. Important insight into s 27 is gained from its predecessor.

\footnotetext{
52 Alison Chetwin, Tony Waldegrave, Kiri Simonsen with Strategic Training and Development Services \& The Family Centre Social Policy Research Unit Speaking about cultural background at sentencing: Section 16 of the Criminal Justice Act 1985 (Ministry of Justice, November 2000) at 138.

${ }^{53}$ For the full provision see appendix B.1.
} 
Section 16 was introduced to the Criminal Justice Bill in 1985, after the Justice Department report addressing "Sentencing trends in District Courts 1979-1983 (Males)" declared a disparity between Māori and non-Māori imprisonment rates even when a comparison was drawn between persons of similar socio-economic status. ${ }^{54}$ The report emphasised the encouragement of alternatives to imprisonment for Māori offenders as a solution. ${ }^{55}$ The Justice Department went on to propose: ${ }^{.6}$

...Māori offenders appearing before a Court for sentence should be entitled to have a person who is familiar with the case advise the Court on the offender's family circumstances and cultural background and on such other matters as the Court considers relevant. Such a right would be in addition to the right to legal representation. A further provision should be added indicating that the Courts have power to allow any offender to call a person to advise the Court on the offender's family circumstances and cultural background and any other matter considered relevant to the Court. This would help to counter any argument that the proposed change discriminates unduly in favour of Māori offenders in comparison with offenders from other racial groups. In our view these new provisions would greatly assist to secure the co-operation of Māori people seeking ways to find alternatives to imprisonment.

Following the Justice Department submission, the Bill included the proposed entitlement to have a person speak on the offender's family circumstances and cultural background in what would be s $16 .^{57}$ Evidently, the Statutes Revision Committee reporting on the Criminal Justice Bill, agreed that Māori rates of imprisonment were concerning. Parliament fully intended to deal with over-representation by means of the provision, by considering the backgrounds of Māori offenders at sentencing.

Dr Cullen, Chairperson for the Statutes Revision Committee, voiced the importance of the addition to the Bill, emphasising the importance of sentences meeting the needs of Māori

\footnotetext{
${ }^{54}$ Department of Justice Criminal Justice Bill No.2 (22 April 1985) at 2.

${ }^{55}$ At 3 .

${ }^{56}$ At 2-3.

${ }^{57}$ Wells $v$ Police, above n 4, at 569.
} 
offenders. ${ }^{58}$ Young Māori offenders were recognised as forming a disproportionately large section of the prison population, "to the shame of us all."59 Parliament was supportive, recognising the need for a specific sentencing provision to address the disproportionate numbers of Māori in prison. A crucial step in reducing the numbers in prison involved the judiciary undertaking their role in acknowledging matters specific to Māori offenders, including backgrounds and historic disadvantage.

In the legislative period between the passage of the Criminal Justice Act and the passage of the Sentencing Act there appears to be no change in Parliament's intent that the Courts have the ability to receive information to enable them to deal with Māori overrepresentation. In fact, s 27 greatly expanded upon the previous provision, indicating the continued importance of dealing with Māori over-representation. There is no reason to suspect the principles underpinning the previous amendment have changed.

\section{Wells v Police}

Wells $v$ Police sheds valuable light on the purpose of s 16. Wells was an appeal to the High Court on the grounds that the sentencing Judge had misinterpreted s 16 of the Criminal Justice Act. ${ }^{60}$ Smellie J undertook an analysis of the purpose of s 16 and determined its enactment was largely due to the disproportionate rate of imprisonment of Māori and the limited alternatives to imprisonment for Māori offenders. ${ }^{61}$ Smellie J acknowledged: ${ }^{62}$

There is, today, a growing (and some would say long overdue) recognition that the Court system in this country based as it is on the Anglo-Saxon traditions of the common law is not always flexible enough to ensure fair and appropriate treatment for all New Zealanders.

\footnotetext{
58 (12 June 1985) 463 NZPD 4759.

59 (12 June 1985) 463 NZPD 4759.

${ }^{60}$ At 566.

${ }^{61}$ At 570.

${ }^{62}$ At 570.
} 
Wells' focus on the legislative purpose for enacting s 16 provides a clear picture of the provision and strong authority for later cases. Parliament envisioned the court would receive information to recognise Māori cultural patterns and alternative programmes for discipline and reformation of Māori offenders.

Later cases have continued to refer to the underlying principles of s 16 articulated in Wells. On appeal, Nishikata $v$ Police ${ }^{63}$ raises the issue of the District Court's failure to consider cultural factors under s 16. Nishikata refers to Wells' discussion of Parliament's intent for a court to receive information on cultural patterns and alternatives to imprisonment for Māori. ${ }^{64}$ Similarly, the Judge notes s 16's general application to avoid suggestion of preferential treatment. ${ }^{65}$ This decision affirmed Wells ' interpretation of Parliament's intent.

Wells' analysis of Parliament's intent is no longer referred to by courts following the introduction of s 27. However, Wells remains highly persuasive as Parliament has continued in the same direction set by the previous provision. Wells' interpretation of Parliamentary signals are not considered by either the Court of Appeal or Mika's counsel. No strong signal from Parliament exists to indicate the courts are intended to deviate from the Wells interpretation.

The Parliamentary material on s 16 and the Wells decision, demonstrate s 27 was originally introduced by Parliament as part of an ongoing, and strengthened, response to the overrepresentation of Māori in New Zealand's prison population. Parliament considered it important to gather information concerning Māori offender's backgrounds and sentencing options in an attempt to curb the number of Māori in prison. Section 27 was enacted to remedy the statistical imbalance to some extent. The Courts have underutilised this provision, undermining this purpose.

\footnotetext{
${ }^{63}$ Nishikata v Police HC Wellington AP126/99, 22 July 1999.

${ }^{64}$ At 6.

${ }^{65}$ At 7.
} 


\section{Section 27(5) Discretion Available to the Judiciary}

\section{A The Court's Failure to Exercise this Discretion}

$R v$ Mika was a step in the wrong direction for the New Zealand judiciary dealing with the over-representation of Māori in New Zealand prisons. The Court of Appeal, in failing to pay attention to the New Zealand jurisprudence, ignored a crucial sentencing provision for Māori offenders. Wells provided the Court of Appeal with precedent. In neglecting to look at the legislative history, the Court failed to apply s 27 as Parliament intended. Without looking to the appropriate provisions enabling a court to consider the issues Mika raised, including the systemic and background factors contributing to offending, the court dismissed Mika's appeal in a concise 16-paragraph judgment. Harris observed: ${ }^{66}$

This was not an easy case for the Court of Appeal to deal with. The issues are controversial, and were likely to attract attention regardless of the Court's conclusion... the Court's judgment is ultimately unpersuasive and does not engage in sufficient depth with the complex and weighty issues at play.

Following their acceptance of the problem of over-representation of Māori in New Zealand prisons, the Court of Appeal should have exercised their discretion under s 27(5) to suggest Mika call on someone to speak on his cultural background, rather than pursue the 10 per cent discount.

Mika's case was not well argued by counsel; both the Judges and counsel were aware of s 27, yet no use was made of it. Essentially, the burden falls to the judiciary to seek the cultural information under s 27(5). After determining the impact of Mr Mika's cultural background and other factors, the sentence arrived at may have been the same. However, this does not detract from the fact that the Court failed in its duty to take account of Parliament's intention and to ensure it had relevant cultural material before it. Harris

${ }^{66}$ Harris, above $\mathrm{n} 40$, at 22-23. 
suggests Mika is an example of the New Zealand judiciary lacking boldness and avoiding tackling issues of indigenous over-representation in prisons. ${ }^{67}$ The Court was facing an unpopular decision, if they were to factor into the sentencing equation the cultural background of the offender, as Parliament intended, the public may have viewed it as preferentialism. Ultimately, the decision lacked boldness and, left a gap where analysis of Parliament's intent and the statutory context should have taken place.

\section{B Factors to Consider in Exercise of Discretion}

\section{$1 \quad$ Underutilisation of section 27}

Research indicates s 27 is used infrequently. Judge O'Driscoll described s 27 as one of the most underutilised and unknown provisions in the Sentencing Act. ${ }^{68}$ Halls Sentencing recognised s 27 is widely unknown, but when in play the provision could enhance both the content and process of sentencing delivering positive sentencing effects in the cases where it is present. ${ }^{69}$ However, it continues to be underutilised and overlooked as a key provision, as evidenced by the case of $R v M i k a$.

Section 16 was similarly underutilised. A Ministry of Justice survey conducted in 1999/2000, aimed to examine the uses and perceptions of s 16 and identify possible improvements to the provision or its implementation. ${ }^{70}$ The survey was sent to 707 participants, including judges, lawyers, Community Probation Service staff and community organisations, with a response rate of 61 per cent. ${ }^{71}$ The survey identified a significant fraction of those working within the criminal justice system, had never encountered s $16 .{ }^{72}$ The survey revealed 44 per cent of lawyers and 14 per cent of judges (these numbers are assumed to be greater than the survey indicated due to a lack of

\footnotetext{
${ }^{67}$ Harris, above $\mathrm{n} 40$, at 24.

${ }^{68}$ Judge O’Driscoll “A powerful mitigating tool” (2012) 11 NZLJ 358 at 358.

${ }^{69}$ Geoffrey Hall (ed) Hall's Sentencing (online looseleaf ed, LexisNexis) at [SA27.1].

${ }^{70}$ Alison Chetwin, Tony Waldegrave, Kiri Simonsen with Strategic Training and Development Services \& The Family Centre Social Policy Research, above n 52, at iii.

${ }^{71}$ At 115.

${ }^{72}$ At 138 .
} 
participation by those who have not encountered s 16) had not been involved with $\mathrm{s} 16^{73}$ The section's underutilisation was attributed to the general lack of awareness of its availability and use. $^{74}$ Another significant section of respondents believed there was defiance among those working in the court system to make or receive s 16 submissions. ${ }^{75}$ Overall, only 14 per cent of respondents thought the provision was used as frequently as it could be. ${ }^{76}$ These results indicate a large portion of cases are not utilising s 27 to its full potential.

The survey indicated Māori offenders' utilised s 16 most commonly, followed by Pacific Peoples. ${ }^{77}$ The people most likely to speak to the court were members of the whānau, while community groups and kaumātua were common spokespeople also. ${ }^{78}$ In 45 per cent of the cases reported in the survey, the likely sentence was imprisonment. ${ }^{79}$ However, in onethird of those cases the imprisonment was suspended and for a quarter of the cases a community-based sentence was imposed. ${ }^{80}$ This indicates s 16 had a positive impact on the sentences imposed when utilised.

In response to the underutilisation, more than half of the survey respondents thought judges should promote $\mathrm{s} 16 .^{81}$ The role of the judge was interpreted as taking a proactive stance, this would involve the judge making the appropriate enquiries at the sentencing stage to ascertain whether matters should be brought to the attention of the court. ${ }^{82}$ One judge as a matter of course enquired whether there was anyone present who wished to speak on behalf of the offender ${ }^{83}$ It was possible for a judge to anticipate $s 16$ at the point where the case

\footnotetext{
${ }^{73}$ At 138 .

${ }^{74}$ At 138 .

${ }^{75}$ At 138.

${ }^{76}$ At 138 .

${ }^{77}$ At 137.

${ }^{78}$ At 137.

${ }^{79}$ At 137.

${ }^{80}$ At 137.

${ }^{81}$ At 147.

${ }^{82}$ At 147.

${ }^{83}$ At 147.
} 
was remanded for a s 23 pre-sentence report. ${ }^{84}$ Notably, the aim of s 16, to encourage alternative sentences to imprisonment, particularly in the case of Māori, has largely been unrealised. The report likely had an impact on the expansion of the subsequent s 27.

\section{The judiciary's acknowledgment of the importance of a section 27 request}

The New Zealand judiciary is aware of the importance of s 27 when requested, evidenced by $R v$ Bhaskaran. ${ }^{85}$ Bhaskaran appealed against his sentence of three years and three months imprisonment, claiming representatives of the Whakatōhea Māori Trust Board were not allowed to speak on his behalf at court before the sentence was decided in accordance with s $27 .{ }^{86}$ Counsel for the defendant informed the Judge of the presence of representatives to speak on the matters envisaged by s 27 and its reference to personal, family, whānau, community, and cultural background of the offender. ${ }^{87}$ The Judge refused to hear from the Whakatōhea Māori Trust Board, without any reasons given under s 27(4), and no special reasons were apparent. ${ }^{88}$

The Court of Appeal was "troubled" by the Judge's decision not to hear a person speak on behalf of the offender. ${ }^{89}$ The Court recognised community support and encouragement for rehabilitation may be relevant to the nature or length of the sentence. ${ }^{90}$ The support systems offered by family, whānau and the community to assist rehabilitation may be important factors in mitigating a sentence influenced by considerations of personal deterrence and rehabilitation. ${ }^{91}$ The Court declared a court "must be astute to recognise the valuable assistance it may obtain from another cultural, ethnic or other community insight, including

\footnotetext{
${ }^{84}$ At 147.

${ }^{85} R$ v Bhaskaran [2003] BCL 89 (CA).

${ }^{86}$ At [10].

${ }^{87}$ At [7].

${ }^{88}$ At [15].

${ }^{89}$ At [13].

${ }^{90}$ At [13].

${ }^{91}$ At [13].
} 
on matters of penal concern." 92 The appellant's sentence was reduced by three months for the trial Judge's failure to adhere to s $27 .{ }^{93}$ The Court of Appeal in Bhaskaran placed high importance on the offender's s 27 request. Mika is different because the offender did not seek to utilise s 27. Nevertheless, s 27 remains important as the judiciary have discretion to suggest the provision be put to use. The judiciary should exercise this duty where Parliament envisioned, to protect from injustices.

\section{$V$ Other Factors Indicating the Court was Misguided}

\section{A Focus on the Sentencing Discount}

The High Court judgment focused on counsel's argument that Mika's background and the "social deprivation of Māori" entitled him to a 10 per cent discount on his sentence. ${ }^{94}$ Gendall $\mathrm{J}$ in the High Court acknowledged s 8 of the Sentencing Act allows cultural issues to be taken into account, particularly in regard to innovative sentencing. ${ }^{95}$ But he denies the blanket discount on the basis that "Parliament did not say that if you are a member of a particular race, culture or ethnic group, this means on its own that you are entitled to a sentencing discount." ${ }^{96}$ It was open to Mika to place a request for a person to speak under s 27 on appeal, but this was not utilised by counsel in either the High Court or the Court of Appeal. Gendall J acknowledged "no request was made to the Court under s 27 of the Sentencing Act to put before it any specific evidence related to the personal, family, whānau, community and cultural background of Mr Mika."97

While it is a far stretch to envision Parliament intended for a fixed sentencing discount to apply to members of a particular race, culture or ethnic group, the judiciary had the tools

\footnotetext{
${ }^{92}$ At [13].

${ }^{93}$ At [18].

${ }^{94} R v$ Mika, above $\mathrm{n} 2$, at [59].

${ }^{95}$ At [67].

${ }^{96}$ At [67].

${ }^{97}$ At [66].
} 
to acknowledge and attempt to remedy the over-representation. Section 27 was an important provision in this case, and while it remains a presumptive entitlement, the option to apply it was available to the Court under s 27(5). The Judiciary had the opportunity to acknowledge the over-representation of Māori and subsequently address the issue by offering further guidance after Wells $v$ Police for how the Sentencing Act, s 27 could be utilised for Māori offenders. The focus on the sentencing discount by both courts meant the judiciary failed to investigate whether Parliament had provided guidance on the issue of Māori over-representation and whether s 27 and s 8 could be of use. Counsel and the judiciary's failure to utilise s 27 may point to a lack of willingness to apply the sentencing provision as intended.

\section{B Insufficient Work Done on how to Reflect Section 27 in Sentencing Options}

The discount argument scared the Court of Appeal in Mika. There were many provisions available to the Court to take into account this material without introducing a discount. Section 27 did not need to be ignored because Mika argued for a discount. Section 27 may prove useful when deciding between a custodial sentence and non-custodial, or between custodial sentences of different lengths. No assistance is currently available to judges in incorporating considerations of Māori offenders' backgrounds and historic disadvantage. The lack of boldness shown by the judiciary could be attributed to confusion regarding the practical application of s 27 in sentencing. However, there is no excuse for the judiciary not to exercise justice, simply because this work has not yet been done.

\section{Failure to Take into Account Overseas Jurisdictions}

New Zealand's judiciary can learn from the Canadian courts' willingness to consider cultural factors influencing offending and sentencing. Should the New Zealand judiciary decide to utilise s 27 for its purpose, the Canadian jurisprudence provides valuable insight into the section's practical application. 
Canada has a similar problem of over-representation of indigenous peoples to New Zealand, with the number of Aboriginal adults in sentenced custody disproportionately high. ${ }^{98}$ In 2010/2011 the number of Aboriginal people in custody, both territorial and federal, was about seven to eight times higher than the proportion of Aboriginal people in the general adult population. ${ }^{99}$ The issue became one of great importance; this is reflected in the Canadian Supreme Court decision $R v$ Gladue, ${ }^{100}$ considered by some to be the most significant development in the criminal law for Aboriginal people in the past 25 years. ${ }^{101}$ The Supreme Court acknowledged their role in the process of convicting and sentencing Aboriginal offenders. Subsequently, the Canadian Criminal Code ${ }^{102}$ s 718.2(e) was interpreted so as to address the problem of over-representation of Aboriginal offenders in prison. The Court of Appeal decision in Mika appears to be out of step with not only its own jurisprudence, but similarly Canadian jurisprudence.

The Canadian Criminal Code set out an innovative sentencing principle in section $718.2(\mathrm{e}):^{103}$

718.2 A court that imposes a sentence shall also take into consideration the following principles: (e) all available sanctions other than imprisonment that are reasonable in the circumstances should be considered for all offenders, with particular attention to the circumstances of aboriginal offenders.

This directive was adopted due to the increasing over-representation of Aboriginal people in Canadian prisons. This unique section is the only one among common law countries

\footnotetext{
${ }_{98}$ Mia Dauvergne "Adult correctional statistics in Canada, 2010/2011" (2012) Statistics Canada

$<$ http://www.statcan.gc.ca/pub/85-002-x/2012001/article/11715-eng.htm\#a7> at 11.

${ }^{99}$ Dauvergne, above $\mathrm{n} 98$, at 11.

${ }^{100} R v$ Gladue [1999] 1 SCR 688 (SCC).

${ }^{101}$ Jonathan Rudin "Aboriginal Over-representation and R. v. Gladue: Where We Were, Where We Are and Where We Might Be Going” (2008) 40 S.C.L.R. 687 at 687.

${ }^{102}$ Criminal Code RSC 1985, c C-46.

${ }^{103}$ Criminal Code RSC 1985, c C-46, s 718.2(e) (emphasis added).
} 
directing judges to consider specifically the circumstances of Aboriginal offenders. ${ }^{104}$ Alan Rock, Justice Minister at the time, explained the section aimed to encourage the courts to look to alternatives to imprisonment, where it is consistent with the public safety, and not simply to resort to the easy option. ${ }^{105}$ The legislature issued clear instructions to the Judiciary emphasising the importance of ensuring the sentencing of Aboriginal offenders is appropriate in the circumstances.

The Supreme Court tested the section parameters in the 1999 case of $R v$ Gladue. Gladue was concerned with the interpretation of s 718.2(e). The case concerned Jamie Tanis Gladue, an Aboriginal woman, who pled guilty to manslaughter for the killing of her husband and was sentenced to three years imprisonment. ${ }^{106}$ The Supreme Court, in a unanimous decision, engaged in a discussion of the purposes and reasons behind s 718.2(e), additionally critiquing the high rate of incarceration in Canada generally. The judgment, delivered by Cory and Iacobucci JJ, made important observations regarding the nature of Aboriginal over-representation in Canada: ${ }^{107}$

The figures are stark and reflect what may fairly be termed a crisis in the Canadian criminal justice system. The drastic over-representation of aboriginal peoples within both the Canadian prison population and the criminal justice system reveals a sad and pressing social problem. It is reasonable to assume that Parliament, in singling out aboriginal offenders for distinct sentencing treatment in s. 718.2(e), intended to attempt to redress this social problem to some degree. The provision may properly be seen as Parliament's direction to members of the judiciary to inquire into the causes of the problem and to endeavour to remedy it, to the extent that a remedy is possible through the sentencing process.

Gladue was a moment of clarity for the Canadian Supreme Court. The judiciary acknowledged and took responsibility for their role in the over-representation crisis. The

\footnotetext{
${ }^{104}$ Rudin, above $\mathrm{n} 101$, at $689-690$.

${ }^{105}$ Rudin, above $\mathrm{n} 101$, at 690.

${ }^{106}$ At 688 .

${ }^{107}$ At [64].
} 
Court recognised many factors contribute to the over-representation of Aboriginal offenders including poverty, substance abuse, and lack of education and employment opportunities. ${ }^{108}$ As the decision-makers with the power to determine directly whether an Aboriginal offender will be incarcerated or whether another sentencing option will be employed, the Canadian Supreme Court acknowledged the important role the judiciary play. ${ }^{109}$ The Court emphasised the legislature's intention and the pressing need for judicial action. ${ }^{110}$ Ultimately, the Court interpreted Parliament's signals to mean cultural factors ought not to be ignored and underutilised. The Court of Appeal in Mika had the opportunity to consider Parliament's intent and the earlier decision of Wells in deciding whether to utilise their s 27(5) discretion, yet declined to do so.

The Supreme Court offered guidance for sentencing an Aboriginal offender in line with section 718.2(e). The judiciary focused on the distinct situation of Aboriginal peoples in Canada, encompassing a wide range of circumstances, including, most particularly: ${ }^{111}$

(A) The unique systemic or background factors which may have played a part in bringing the particular aboriginal offender before the courts; and

(B) The types of sentencing procedures and sanctions which may be appropriate in the circumstances for the offender because of his or her particular aboriginal heritage or connection.

Gladue declared s 718.2(e) reports compulsory when sentencing an Aboriginal offender; in all cases judicial notice must be taken of the systemic or background factors and alternative sentencing options. ${ }^{112}$ The Court expected counsel would help the judge prepare the relevant background evidence for cultural considerations at sentencing. ${ }^{113}$ Aboriginal

\footnotetext{
108 At [65].

109 At [65].

110 At [64].

111 At [66].

112 At [83].

113 At [83].
} 
offenders retain the ability to waive the right to have attention paid to their particular circumstances. $^{114}$

The provision is not a 'free pass' for a lighter sentence, the Aboriginal offenders must show unique systemic background factors may have contributed to the offending, as well as alternative sanctions that may be appropriate in the circumstances. A blanket discount is not applied to their sentence by virtue solely of being Aboriginal. ${ }^{115}$ In order to adduce the appropriate sentence to fit the offender, the judge must have information on the offender, their background and the systemic factors that have played a role in their life. Justice Knazan at the Ontario Conference of Judges and the Canadian Association of Provincial Court Judges annual conference in 2000 announced almost two years after $R v$ Gladue confusion remained over the application of the section. ${ }^{116}$ The problems were basic, including the difficulty for judges in knowing when an Aboriginal offender was before the court. ${ }^{117}$ The conference concerned the creation of a specialised Gladue court dealing with the sentencing of Aboriginal people. The Gladue Court began hearing cases in 2001, and expanded to create two other Gladue Courts dealing only with bail hearings and sentencing Aboriginal offenders. ${ }^{118}$

The role of the Gladue Caseworker, involved preparing written reports on Aboriginal offenders at the request of the judge, defence or Crown to support the Gladue Courts. ${ }^{119}$ These reports, requested by a judge under s 718.2(e), detail extensively the offender's life circumstances, including interviews with friends, family members and people who may be able to provide insight into the offender's life. ${ }^{120}$ Further, the reports illustrate the systemic factors that have affected Aboriginal people and put forward solid plans for alternative

\footnotetext{
114 At [83].

115 Rudin, above n 101, at 703.

${ }^{116}$ Rudin, above n 101, at 704-705.

${ }^{117}$ Rudin, above n 101, at 705.

118 Rudin, above n 101, at 705 .

119 Rudin, above n 101, at 705 .

${ }^{120}$ Rudin, above n 101, at 705 .
} 
sentences to imprisonment. ${ }^{121}$ Research suggests the Gladue reports have seen a positive impact on the sentences handed down to Aboriginal offenders. ${ }^{122}$

In 2013, the Legal Services Society (LSS) of Canada, evaluated the results of the Gladue Report Pilot Project where trained writers prepare Gladue reports for Aboriginal offenders. ${ }^{123}$ The programme aimed to provide Aboriginal people with comprehensive Gladue reports when facing sentencing or bail hearings. ${ }^{124}$ LSS compared case outcomes for 42 clients with a Gladue report and matched this with similar cases where the Aboriginal client did not utilise the Gladue report. ${ }^{125}$ Fewer Gladue clients received a sentence of incarceration for the same offence. ${ }^{126}$ Further, when comparing a client's previous sentence with their current sentence for the same offence (utilising a Gladue report), the results indicated Gladue reports decrease the severity of the sentence. ${ }^{127}$ When an offender commits the same offence, it is expected their sentence will increase or remain the same. However, the Gladue results indicate 76 per cent of clients received a shorter sentence the second time they committed the same offence. ${ }^{128}$ The LSS results suggest Gladue reports may make an impact on the number of Aboriginal offenders in Canadian prisons.

New Zealand can learn from the Canadian approach to 718.2(e). Practical issues will arise in applying a section like this and Canada's approach has not been without difficulty. To make the best use of s 27 of the Sentencing Act, the New Zealand judiciary would need to accept Parliament's intention for the provision to apply to Māori offenders appearing for sentencing. In line with the intention of the legislature, judges should proactively seek

\footnotetext{
${ }^{121}$ Rudin, above $\mathrm{n} 101$, at 705.

${ }^{122}$ Legal Services Society "Evaluation of Gladue Report Pilot Project” (June 2013) Legal Services Society: Aboriginal Services

$<$ http://www.legalaid.bc.ca/assets/aboutUs/reports/aboriginalServices/gladueReportDisbursementEvaluatio nJune2013.pdf>.

${ }^{123}$ Legal Services Society, above n 122, at i.

124 At 5.

${ }^{125}$ At 21.

${ }^{126}$ At 22 .

127 At $24-25$.

${ }^{128}$ At 24-25.
} 
information under s 27 and indicate cultural factors will be considered under the section. Encouragement of use of the provision will inevitably increase awareness of the section. In practice, counsel will likely be responsible for preparing the s 27 requests and the particular people to speak on the background of the offender in court. Section 27 has the potential to be a common sentencing practice in mainstream criminal courts, should the judiciary utilise it for the purpose for which it was created.

\section{Conclusion}

This paper demonstrates the flaws in the Court of Appeal's decision in Mika. The causes of over-representation are numerous, and no one fix exists. However, where a practical solution has been established by the legislature, it is the role of the judiciary not to shirk their responsibilities when they prove difficult. The Court of Appeal did not engage with the provision and New Zealand's jurisprudence to the extent necessary in the case, perhaps for fear of the 'ethnicity' factor in sentencing. The judiciary's failure to acknowledge Parliament intended s 27 to apply to Māori offenders especially is disappointing considering the major role they play in sentencing. The judiciary should encourage the use of s 27, especially where a Māori offender is arguing cultural factors should be considered in determining a sentence. This would be consistent with the section's purpose and may work to reduce the disproportionate numbers of Māori in New Zealand prisons. Justice Joseph Williams' 2013 Harkness Henry Lecture discusses the use of s 27 in the Matariki Court; a 's 27 Court' that focuses on receiving information about cultural and family background to inform the sentencing process; this is a development to watch in future. ${ }^{129}$

The Court in Mika v R dismiss Mika's argument for the court to consider his Māori heritage and associated disadvantages, without any real discussion of Parliament's attempts to reduce the over-representation of Māori in the criminal justice system. If the issue were to come before a New Zealand appellate court again, the judiciary should take an initiative

\footnotetext{
${ }^{129}$ Justice Joseph Williams "Lex Aotearoa: An Heroic Attempt to Map the Māori Dimension in Modern New Zealand Law" (2013) 21 WLR 1 at 27.
} 
similar to Smellie J in Wells and look to Parliament's intent. It would not constitute judicial overreach to interpret the provision with special consideration for Māori, as feared by the Court in Mika. Further, New Zealand could learn from the steps taken in $R v$ Gladue, providing an important indication of the practical issues to be addressed in applying the section. The Canadian jurisprudence provides valuable insight and lessons into the process taken to apply a section similar to New Zealand's s 27, in an effort to reduce disproportionate numbers in prison.

The failure by the Court of Appeal in Mika $v R$ is concerning, the sections were glossed over without any real application to Mika's cultural background and the systemic disadvantages he may have suffered. The New Zealand judiciary have further work to do in this area to remedy this. 


\section{Appendices}

\section{A Sentencing Act 2002 provisions}

\section{$1 \quad$ Section 8}

8 Principles of sentencing or otherwise dealing with offenders In sentencing or otherwise dealing with an offender the court-

(a) must take into account the gravity of the offending in the particular case, including the degree of culpability of the offender; and

(b) must take into account the seriousness of the type of offence in comparison with other types of offences, as indicated by the maximum penalties prescribed for the offences; and

(c) must impose the maximum penalty prescribed for the offence if the offending is within the most serious of cases for which that penalty is prescribed, unless circumstances relating to the offender make that inappropriate; and

(d) must impose a penalty near to the maximum prescribed for the offence if the offending is near to the most serious of cases for which that penalty is prescribed, unless circumstances relating to the offender make that inappropriate; and

(e) must take into account the general desirability of consistency with appropriate sentencing levels and other means of dealing with offenders in respect of similar offenders committing similar offences in similar circumstances; and

(f) must take into account any information provided to the court concerning the effect of the offending on the victim; and

(g) must impose the least restrictive outcome that is appropriate in the circumstances, in accordance with the hierarchy of sentences and orders set out in section 10A; and

(h) must take into account any particular circumstances of the offender that mean that a sentence or other means of dealing with the offender that would otherwise be appropriate would, in the particular instance, be disproportionately severe; and

(i) must take into account the offender's personal, family, whanau, community, and cultural background in imposing a sentence or other means of dealing with the offender with a partly or wholly rehabilitative purpose; and

(j) must take into account any outcomes of restorative justice processes that have occurred, or that the court is satisfied are likely to occur, in relation to the particular case (including, without limitation, anything referred to in section 10).

\section{Section 25}

25 Power of adjournment for inquiries as to suitable punishment

(1) A court may adjourn the proceedings in respect of any offence after the offender has been found guilty or has pleaded guilty and before the offender has been sentenced or otherwise dealt with for any 1 or more of the following purposes:

(a) to enable inquiries to be made or to determine the most suitable method of dealing with the case: 
(b) to enable a restorative justice process to occur:

(c) to enable a restorative justice agreement to be fulfilled:

(d) to enable a rehabilitation programme or course of action to be undertaken:

(da) to determine whether to impose an instrument forfeiture order and, if so, the terms of that order:

(e) to enable the court to take account of the offender's response to any process, agreement, programme, or course of action referred to in paragraph (b), (c), or $(\mathrm{d})$.

\section{Section 26}

26 Pre-sentence reports

(1) Except as provided in section 26A, if an offender who is charged with an offence punishable by imprisonment is found guilty or pleads guilty, the court may direct a probation officer to prepare a report for the court in accordance with subsection (2).

(2) A pre-sentence report may include-

(a) information regarding the personal, family, whānau, community, and cultural background, and social circumstances of the offender:

(b) information regarding the factors contributing to the offence, and the rehabilitative needs of the offender:

(c) information regarding any offer, agreement, response, or measure of a kind referred to in section 10(1) or the outcome of any other restorative justice processes that have occurred in relation to the case:

(d) recommendations on the appropriate sentence or other disposition of the case, taking into account the risk of further offending by the offender:

(e) in the case of a proposed sentence of supervision, intensive supervision, or home detention, recommendations on the appropriate conditions of that sentence:

(f) in the case of a proposed sentence of supervision, intensive supervision, or home detention involving 1 or more programmes,-

(i) a report on the programme or programmes, including a general description of the conditions that the offender will have to abide by; and

(ii) confirmation that the report has been made available to the offender:

(g) in the case of a proposed sentence of supervision, intensive supervision, or home detention involving a special condition requiring the offender to take prescription medication, confirmation that the offender-

(i) has been fully advised by a person who is qualified to prescribe that medication about the nature and likely or intended effect of the medication and any known risks; and

(ii) consents to taking the prescription medication: 
(h) in the case of a proposed sentence of community work, -

(i) information regarding the availability of community work of a kind referred to in section 63 in the area in which the offender will reside; and

(ii) recommendations on whether the court should authorise, under section 66A, hours of work to be spent undertaking training in basic work and living skills.

(3) The court must not direct the preparation of a report under subsection (1) on any aspects of the personal characteristics or personal history of an offender if a report covering those aspects is readily available to the court and there is no reason to believe that there has been any change of significance to the court since the report was prepared.

(4) On directing the preparation of a report under subsection (1), the court may indicate to the probation officer the type of sentence or other mode of disposition that the court is considering, and may also give any other guidance to the probation officer that will assist the officer to prepare the report.

(5) If a court has directed the preparation of a report under subsection (1), the probation officer charged with the preparation of the report may seek the further directions of the court on-

(a) any particular item of information sought by the court; or

(b) any alternative sentence or other mode of disposition that may be considered by the court if it appears that the sentence or other mode of disposition under consideration is inappropriate

\section{$4 \quad$ Section 27}

27 Offender may request court to hear person on personal, family, whanau, community, and cultural background of offender

(1) If an offender appears before a court for sentencing, the offender may request the court to hear any person or persons called by the offender to speak on-

(a) the personal, family, whanau, community, and cultural background of the offender:

(b) the way in which that background may have related to the commission of the offence:

(c) any processes that have been tried to resolve, or that are available to resolve, issues relating to the offence, involving the offender and his or her family, whanau, or community and the victim or victims of the offence:

(d) how support from the family, whanau, or community may be available to help prevent further offending by the offender:

(e) how the offender's background, or family, whanau, or community support may be relevant in respect of possible sentences.

(2) The court must hear a person or persons called by the offender under this section on any of the matters specified in subsection (1) unless the court is 
satisfied that there is some special reason that makes this unnecessary or inappropriate.

(3) If the court declines to hear a person called by the offender under this section, the court must give reasons for doing so.

(4) Without limiting any other powers of a court to adjourn, the court may adjourn the proceedings to enable arrangements to be made to hear a person or persons under this section.

(5) If an offender does not make a request under this section, the court may suggest to the offender that it may be of assistance to the court to hear a person or persons called by the offender on any of the matters specified in subsection (1).

\section{B Criminal Justice Act 1985 provisions}

$1 \quad$ Section 16

S 16 Offender may call witness as to cultural and family background -

(1) Where any offender appears before any court for sentence, the offender may request the court to hear any person called by the offender to speak to any of the matters specified in subsection (2) of this section; and the court shall hear that person unless it is satisfied that, because the penalty that may be imposed is fixed by law of for any other special reason, it would not be of assistance to hear that person.

(2) The matters to which a person may be called to speak under subsection (1) of this section are, broadly, the ethnic or cultural background of the offender, the way in which that background may relate to the commission of the offence, and the positive effects that background may have in helping to avoid further offending. 


\section{Word count}

The text of this paper (excluding table of contents, footnotes, appendices and bibliography) comprises approximately 8004 words. 


\section{References List}

\section{A Cases}

1 New Zealand

Mika $v R$ [2013] NZCA 648.

Nishikata v Police HC Wellington AP126/99, 22 July 1999.

$R v$ Bhaskaran [2003] BCL 89 (CA).

$R v$ Mika [2013] NZHC 2357.

Wells $v$ Police [1987] 2 NZLR 560 (HC).

\section{Canada}

$R v$ Gladue [1999] 1 SCR 688.

\section{B Legislation}

$1 \quad$ New Zealand

Crimes Act 1961.

Criminal Justice Act 1985.

Judicature Act 1908.

Land Transport Act 1998.

Sentencing Act 2002.

2 Canada

Criminal Code RSC 1985, c C-46.

\section{Books and Chapters in Books}


Khylee Quince "Māori and the Criminal Justice System in New Zealand" in Warren Brookbanks and Julia Tolmie (eds) Criminal Justice in New Zealand (LexisNexis NZ, Wellington, 2007) 333.

Māmari Stephens and Mary Boyce (eds) He Papakupu Reo Ture: A Dictionary of Māori Legal Terms (LexisNexis, Wellington, 2013).

\section{Looseleaf Texts}

Geoffrey Hall (ed) Hall's Sentencing (online looseleaf ed, LexisNexis).

Bruce Robertson (ed) Adams on Criminal Law - Sentencing (online looseleaf ed, Brookers).

\section{E Journal Articles}

Max Harris "Criminal law, sentencing and ethnicity - sensible [or] superficial?" (2014) February Māori LR 20.

Judge O’Driscoll “A powerful mitigating tool” (2012) 11 NZLJ 358.

Jonathan Rudin "Aboriginal Over-representation and R. v. Gladue: Where We Were, Where We Are and Where We Might Be Going” (2008) 40 S.C.L.R. 687.

Valmaine Toki "Domestic Violence and Women: Can a Therapeutic Jurisprudence Approach Assist?” (2009) 78 Rev. Jur. U.P.R. 61.

Justice Joseph Williams "Lex Aotearoa: An Heroic Attempt to Map the Māori Dimension in Modern New Zealand Law" (2013) 21 WLR 1.

\section{F Hansard}

(12 June 1985) 463 NZPD 4759.

(23 July 1985) 464 NZPD 5834.

\section{G Government Papers and Reports}

Alison Chetwin, Tony Waldegrave, Kiri Simonsen with Strategic Training and Development Services \& The Family Centre Social Policy Research Unit Speaking about 
cultural background at sentencing: Section 16 of the Criminal Justice Act 1985 (Ministry of Justice, November 2000).

Department of Corrections Over-representation of Māori in the criminal justice system: An exploratory report (September 2007).

Department of Justice Criminal Justice Bill No.2 (22 April 1985).

Ministry of Justice Trends in Conviction and Sentencing - Court statistics for adults (aged 17 and over) for year ended June 2013 (2013).

Ministry of Justice United Nations convention against torture: New Zealand draft periodic report 6 (2013).

Bronwyn Morrison Identifying and Responding to Bias in the Criminal Justice System: A Review of International and New Zealand Research (Ministry of Justice, November 2009).

\section{H Internet Materials}

David Clarkson "Mob member wants short sentence for being Māori” (20 November 2013) Stuff < http://www.stuff.co.nz/national/crime/9422033/Mob-member-wants-shortsentence-for-being-Maori>.

Mia Dauvergne "Adult correctional statistics in Canada, 2010/2011" (2012) Statistics Canada <http://www.statcan.gc.ca/pub/85-002-x/2012001/article/11715-eng.htm\#a7>.

Sam Jeffs "Māori Overrepresentation and the Sentencing Act: The Role of Cultural Background" (19 September 2013) New Zealand Human Rights Blog $<$ http://nzhumanrightsblog.com/policy/maori-overrepresentation-and-the-sentencing-actthe-role-of-cultural-background/\#more-517>.

Legal Services Society "Evaluation of Gladue Report Pilot Project” (June 2013) Legal Services Society: Aboriginal Services

$<$ http://www.legalaid.bc.ca/assets/aboutUs/reports/aboriginalServices/gladueReportDisbu rsementEvaluationJune2013.pdf>.

Kim Workman "Māori Over-representation in the Criminal Justice System - Does Structural Discrimination Have Anything to Do with It?" (8 November 2011) Rethinking Crime and Punishment

$<$ http://www.rethinking.org.nz/assets/Newsletter_PDF/Issue_105/01_Structural_Discrimi nation_in_the_CJS.pdf $>$. 